Sexual Chemistry 
This page intentionally left blank 


\section{Sexual Chemistry}

A History of the Contraceptive Pill

With a New Preface

Lara V. Marks

Yale UNIVERSITY PRESS

New Haven and London 
This paperback edition is dedicated to my children, Daniel and Anna, who inspire me every day with their intelligence, perceptiveness, and happiness.

Copyright $($ 200I by Lara V. Marks

Preface to the paperback edition copyright $(\odot 2010$ by Lara V. Marks

All rights reserved.

This book may not be reproduced, in whole or in part, including illustrations, in any form (beyond that copying permitted by Sections IO7 and Io8 of the U.S. Copyright Law and except by reviewers for the public press), without written permission from the publishers.

Yale University Press books may be purchased in quantity for educational, business, or promotional use. For information, please e-mail sales.press@yale.edu (U.S. office) or sales@yaleup.co.uk (U.K. office).

Printed in the United States of America.

Library of Congress Control Number: 2010927362 ISBN 978-0-300-I679I-7 (pbk.)

A catalogue record for this book is available from the British Library.

This paper meets the requirements of ANSI/NISO Z39.48-1992 (Permanence of Paper). 